\title{
Faktor-Faktor Yang Mempengaruhi Tingkat Profitabilitas Bank Pembiayaan Rakyat Syariah (BPRS) Di Aceh
}

\author{
Muhammad Yasir Yusuf dan Wan Sri Mahriana \\ Fak. Ekonomi dan Bisnis Islam, UIN Ar-Raniry Banda Aceh \\ m.yasiryusuf@gmail.comdan wan sri mahriana@yahoo.com
}

\section{Abstrak}

Profitabilitas bank merupakan kualitas yang dinilai berdasarkan keadaan dan kemampuan suatu bank dalam menghasilkan laba. Penelitian ini bertujuan untuk menguji faktor-faktor yang mempengaruhi tingkat profitabilitas Bank Pembiayaan Rakyat Syariah (BPRS) di Aceh. Profitabilitas dalam penelitian ini diukur dengan menggunakan dua rasio, yaitu return on asset dan return on equity, dengan menggunakan empat faktor yaitu pembiayaan, dana pihak ketiga, financing to deposit ratio dan non performing financing. Metode yang digunakan dalam penelitian ini adalah metode kuantitatif.Adapun sampel yang digunakan adalah Bank Pembiayaan Rakyat Syariah (BPRS) di Aceh yang berjumlah 10 bank dan dipilih berdasarkan metode purposive sampling dengan 140 data pengamatan.Pengamatan dilakukan dari tahun 2010 sampai dengan kuartal III tahun 2015. Hasil penelitian dapat disimpulkan bahwa secara simultan variabel pembiayaan, dana pihak ketiga, financing to deposit ratio dan non performing financing berpengaruh signifikan terhadap return on asset dan return on equity. Untuk pengujian secara parsial, seluruh variabel independen yaitu pembiayaan, dana pihak ketiga, financing to deposit ratio dan non performing financing berpengaruh signifikan terhadap return on asset. Sedangkan terhadap return on equity, hanya variabel dana pihak ketiga dan financing to deposit ratio yang berpengaruh signifikan. Adapun variabel pembiayaan dan non performing financing tidak berpengaruh signifikan terhadap return on equity.

Kata Kunci: Profitabilitas, Bank Pembiayaan Rakyat Syariah 
Abstract

Profitability of banks is assessed by the quality and the ability of a bank to generate profits. The aims of research to examine the factors that generate the profitability of the Syariah Rural Bank in Aceh. Profitability in this study was measured using two ratios; return on assets and return on equity, using four factors: financing, third party funds, financing to deposit ratio and nonperforming financing. The method used in this research is quantitative method. The sample used was the Syariah Rural Bank in Aceh, which amounted to 10 banks and selected based on purposive sampling method with observational data of 140 . Observations were made from 2010 until the third quarter of 2015. The results of this study concluded that simultaneous variable financing, third party funds, financing to deposit ratio and non-performing financing have significant effect on return on assets and return on equity. For the partial test, all independent variables; financing, third party funds, financing to deposit ratio and non-performing financing have significant effect on return on assets. While the return on equity, only variables third party funding and financing to deposit ratio is a significant effect. The financing variables and non-performing financing have no significant effect on return on equity.

Keywords: Profitability and Islamic Rural Bank

\section{PENDAHULUAN}

Salah satu usaha untuk merealisasikan prinsip-prinsip ekonomi Islam dalam aktivitas masyarakat secara nyata adalah dengan mendirikan lembaga-lembaga keuangan yang beroperasi berdasarkan syariat Islam. Dari berbagai jenis lembaga keuangan, perbankan merupakan sektor yang paling memberikan pengaruh yang besar dalam aktivitas perekonomian masyarakat (Iska, 2012).

Berdasarkan Undang-Undang Perbankan Syariah Indonesia Nomor 21 Tahun 2008, disebutkan bahwa bank terdiri atas dua jenis, yaitu bank konvensional dan bank syariah. Bank konvensional adalah bank yang menjalankan kegiatan usahanya secara konvensional yang terdiri atas bank umum konvensional 
dan Bank Perkreditan Rakyat (BPR). Sementara bank syariah adalah bank yang menjalankan kegiatan usahanya berdasarkan prinsip syariah yang terdiri atas bank umum syariah dan Bank Pembiayaan Rakyat Syariah (BPRS).

Dewasa ini, persaingan antar bank syariah semakin ketat, secara langsung maupun tidak langsung hal ini akan berpengaruh terhadap profitabilitas perbankan syariah. Meskipun tujuan dari bank syariah itu bukan hanya sekedar mencari keuntungan, namun kemampuan bank syariah dalam upaya memperoleh keuntungan menjadi indikator penting untuk keberlangsungan bank syariah tersebut.Selain itu, kemampuan bank syariah dalam menghasilkan keuntungan juga menjadi indikator penting untuk mengukur kemampuan bersaing bank syariah dalam jangka panjang.

Bank dalam melakukan kegiatan operasionalnya memiliki tujuan untuk dapat mencapai profitabilitas yang maksimal. Faktor-faktor yang mempengaruhi profitabilitas bank dapat bersumber dari berbagai kinerja operasi yang ditunjukkan oleh beberapa indikator. Salah satu sumber utama indikator yang dijadikan dasar penilaian adalah laporan keuangan bank yang bersangkutan. Berdasarkan laporan itu, akan dapat dihitung sejumlah rasio keuangan yang lazim dijadikan dasar penilaian tingkat kesehatan bank.

Arimi dan Mahfud mengemukakan bahwa setiap perusahaan baik bank maupun non-bank pada suatu waktu (periode tertentu) akan melaporkan semua kegiatan operasional keuangannya. Laporan keuangan ini bertujuan untuk memberikan informasi keuangan, baik kepada pemilik, manajemen, maupun pihak luar yang berkepentingan terhadap laporan tersebut. Laporan keuangan bank menunjukkan kondisi bank secara keseluruhan. Dari laporan ini akan terbaca bagaimana kondisi bank yang sesungguhnya, termasuk kelemahan dan kekuatan yang dimiliki (Arimi dan Mahfuz, 2012).

Dalam penjelasan atas Peraturan Bank Indonesia Nomor 11/23/PBI/2009 tentang Bank Pembiayaan Rakyat Syariah disebutkan bahwa perekonomian nasional perlu memiliki sistem perbankan syariah yang dapat melayani seluruh lapisan masyarakat termasuk kepada pengusaha menengah, kecil dan mikro. Bank Pembiayaan Rakyat Syariah (BPRS) merupakan 
salah satu lembaga keuangan yang mampu untuk melaksanakan peran dalam melayani pengusaha menengah, kecil dan mikro.Untuk meningkatkan pelayanan BPRS kepada usaha menengah, kecil dan mikro secara optimal, BPRS harus sehat dan tangguh. BPRS sebagai salah satu lembaga kepercayaan masyarakat yang kegiatan usahanya berdasarkan prinsip syariah, dituntut agar selalu dapat mengemban amanah dari para pemilik dana dengan cara menyalurkannya untuk usaha produktif dalam rangka meningkatkan taraf hidup masyarakat. Dalam menjalankan kegiatan usahanya, BPRS harus selalu memegang teguh prinsip kehati-hatian serta mampu menerapkan prinsip syariah secara konsisten, sehingga tercipta BPRS yang sehat dan mampu memberikan layanan terbaik kepada masyarakat.

Mengingat pentingnya peranan BPRS dalam membangun perekonomian, maka perlu peningkatan kinerja agar BPRS tetap sehat dan efisien, hal ini akan berdampak kepada tingkat profitabilitas BPRS. Profitabilitas merupakan indikator yang paling tepat untuk menilai kinerja suatu bank. Oleh karena itu, untuk melihat tingkat profitabilitas BPRS perlu diketahui faktor-faktor apa saja yang mempengaruhinya. Adapun rumusan masalah dalam penelitian ini adalah bagaimanapengaruh pembiayaan, dana pihak ketiga, financing to deposit ratio dan non performing financingsecara parsial dan simultan terhadap tingkat profitabilitasBPRS di Aceh.

\section{KAJIAN LITERATUR}

Berdasarkan Undang-Undang Republik Indonesia Nomor 21 Tahun 2008 tentang Perbankan Syariah dalam pasal 1 disebutkan bahwa BPRS adalah bank syariah yang dalam kegiatannya tidak memberikan jasa dalam lalu lintas pembayaran. Soemitra menjelaskan bahwa badan hukum BPRS adalah perseroan terbatas. BPRS hanya boleh dimiliki oleh Warga Negara Indonesia (WNI) dan/atau badan hukum Indonesia, pemerintah daerah atau kemitraan antara WNI atau badan hukum Indonesia dengan pemerintah daerah (Soemitra2010). BPRS sangat berperan dalam memberdayakan ekonomi umat dengan mengembangkan ekonomi golongan lemah yaitu dengan mengembangkan Usaha Mikro, Kecil dan Menengah (UMKM). 
Antonio menyebutkan bahwaBPRS yang menjalankan kegiatannya dengan prinsip bagi hasil juga memiliki beberapa hambatan dalam perkembangannya. Pertama, manajemen bank yang masih kurang profesional. Kedua, risiko yang lebih besar atau ketidakpastian yang lebih tinggi dibandingkan dengan BPR. Ketiga, jaringan operasi yang terbatas, khususnya transaksi sesama bank syariah. Jumlah BPRS di Indonesia masih sangat terbatas sehingga menghambat pengembangannya. Bank syariah tidak dapat melakukan transaksi dengan bank konvensional dengan sistem bunga. Konsekuensinya adalah bank syariah tidak dapat memberikan pelayanan yang luas kepada masyarakat, tidak dapat melakukan kerjasama antar bank syariah, tidak dapat melakukan transaksi penempatan antar bank syariah dan sulit mengatasi likuiditas. Adanya hambatan ini maka akan berdampak kepada tingkat profitabilitas yang diperoleh bank (Antonio, 2008)

Profitabilitas merupakan kemampuan bank menghasilkan laba yang diperoleh dari modal dan aktiva yang dimilikinya (Syamsudin, 2011). Laba adalah tujuan akhir yang ingin dicapai oleh suatu bank di samping hal-hal lainnya. Dengan memperoleh laba yang maksimal seperti yang ditargetkan, bank dapat berbuat banyak bagi kesejahteraan pemilik, karyawan, serta meningkatkan mutu produk dan melakukan investasi baru. Oleh karena itu, manajemen bank dalam praktiknya dituntut harus mampu untuk memenuhi target yang telah ditetapkan (Kasmir, 2011). Tingkat profitabilitas bank merupakan suatu kualitas yang dinilai berdasarkan keadaan/kemampuan suatu bank dalam menghasilkan laba. Selain itu merupakan hasil akhir bersih dari berbagai kebijakan dan keputusan manajemen yang akan memberikan jawaban akhir tentang efektivitas manajemen bank tersebut.

Untuk mengukur tingkat keuntungan suatu bank digunakan rasio profitabilitas. Rasio profitabilitas merupakan rasio untuk menilai kemampuan bank dalam mencari keuntungan. Selain itu, rasio ini juga memberikan ukuran tingkat efektivitas manajemen suatu bank yang ditunjukkan oleh laba yang dihasilkan dari penjualan dan pendapatan investasi (Kasmir, 2015). Penggunaan seluruh atau sebagian rasio profitabilitas tergantung dari kebijakan manajemen. Dalam penelitian ini rasio profitabilitas yang digunakan adalah return 
on asset dan return on equity. Menurut Kasmir return on asset atau hasil pengembalian investasi merupakan rasio yang menunjukkan hasil (return) atas jumlah aktiva yang digunakan dalam bank. Sedangkan return on equity atau pengembalian hasil atas modal merupakan rasio untuk mengukur laba bersih sesudah pajak dengan modal sendiri(Kasmir, 2011).

Ada beberapa penelitian sebelumnya yang membahas tentang profitabilitas.Penelitian yang dilakukan oleh Russely Inti Dwi Permata, Fransisca Yaningwati dan Zahroh Z.A yang meneliti tentang pengaruh pembiayaan mudharabah dan musyarakah terhadap tingkat profitabilitas bank umum syariah yang terdaftar di Bank Indonesia tahun 2009 hingga 2012. Variabel profitabilitas dalam peneltian ini diukur dengan menggunakan return on equity, sedangkan variabel dependen dalam penelitian ini adalah pembiayaan mudharabah dan pembiayaan musyarakah (Russelyet al., 2014). Selanjutnya penelitian yang dilakukan oleh Made Ria Anggreni dan I Made Sadha Suardhika, meneliti tentang pengaruh dana pihak ketiga, kecukupan modal, resiko kredit dan suku bunga kredit terhadap profitabilitas pada bank BUMN tahun 2010 hingga 2012. Variabel profitabilitas dalam penelitian ini diukur dengan menggunakan return on asset, sedangkan variabel dependen dalam penelitian ini adalah dana pihak ketiga, capital adequacy ratio, non performing loan dan suku bunga kredit (Made dan I Made, 2014). Penelitian lainnya dilakukan oleh Millatina Arimi dan Mohammad Kholiq Mahfud yang meneliti tentang faktorfaktor yang mempengaruhi profitabilitas bank umum yang terdaftar di Bursa Efek Indonesia. Penelitian tersebut menguji variabel capital adequacy ratio, non performing loan, net interest margin, biaya operasional per pendapatan operasional dan loan to deposit ratio terhadap profitabilitas yang diukur dengan return on asset. Tahun penelitian yang digunakan adalah tahun 2007 hingga 2010 (Millatina dan Mohammad, 2012).

Di samping itu, juga terdapat beberapa penelitian yang menjelaskan tentang faktor-faktor yang mempengaruhi tingkat profitabilitas sebuah bank. Hasil penelitian yang dilakukan oleh Fahrulet.al. (2012) dan Permata et.al. (2014) menunjukkan bahwa pembiayaan berpengaruh terhadap tingkat profitabilitas bank.Penelitian Anggreni dan Suardhika (2014) menunjukkan bahwa dana pihak ketiga berpengaruh terhadap tingkat 
profitabilitas. Penelitian Suryani (2011) menjelaskan bahwa jika rasio Financing to deposit ratiobank berada pada standar yang ditetapkan oleh Bank Indonesia, maka laba yang diperoleh bank tersebut akan meningkat (dengan asumsi bank tersebut mampu menyalurkan pembiayaannya dengan efektif). Dengan penyaluran danapihak ketiga yang besar maka profitabilitas bank akansemakin meningkat, sehingga financing to deposit ratio berpengaruhpositif terhadap profitabilitas. Di sisi lain tingkat risiko pembiayaan (NPF) juga menjadi faktor yang mempengaruhi tingkat profitabilitas (Fahrul et.al., 2012).

Oleh karena itu, penelitian ini akan menggunakan variabel dependen pembiayaan, dana pihak ketiga, financing to deposit ratio dan non performing financing. Sedangkan variabel profitabilitas di ukur dengan menggunakan dua rasio yaitu return on asset dan return on equity. Hal ini berbeda dengan penelitian-penelitaian sebelumnya yang hanya menggunakan salah satu dari kedua rasio tersebut. Oleh karena itu skema paradigma penelitian ini adalah berusaha melihat dan membuktikan hubungan pembiayaan, dana pihak ketiga, financing to deposit ratio dan non performing financing terhadap tingkat profitabilitas. Skemanya dapat dilihat pada gambar berikut:

Gambar 1: Skema Penelitian

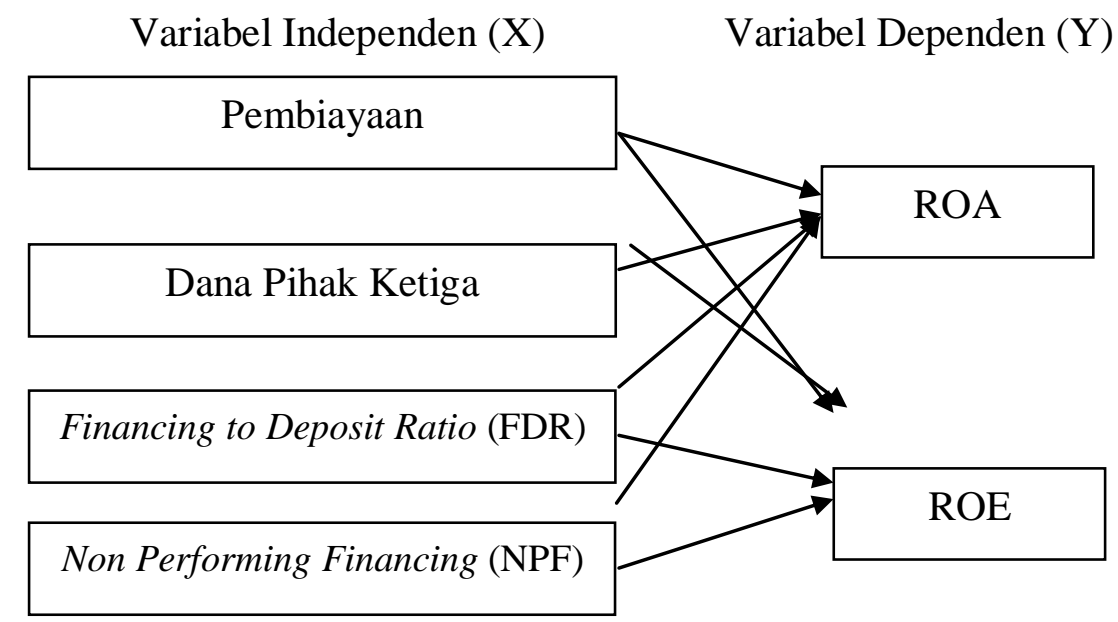




\section{METODE PENELITIAN}

\section{Pendekatan Penelitian}

Penelitian ini menggunakan metode kuantitatif.Pada metode kuantitatif, data penelitian yang digunakan berupa angka-angka dan analisis menggunakan statistik (Sugiyono, 2012).Metode kuantitatif digunakan untuk meneliti pada populasi atau sampel tertentu, pengumpulan data menggunakan instrumen penelitian dan analisis data bertujuan untuk menguji hipotesis yang telah ditetapkan.

\section{Populasi dan Sampel Penelitian}

Populasi dalam penelitian ini adalah BPRS di Aceh yang beroperasi penuh dari tahun 2010 sampai kuartal III tahun 2015. Teknik pengambilan sampel menggunakan metode purposive sampling yang menentukan sampel dengan pertimbangan atau kriteria tertentu (Sugiyono 2014). Nama-nama BPRS yang dijadikan sampel dalam penelitian ini adalah (1) Baiturrahman, (2) Hareukat, (3) Tgk. Chik Dipante, (4) Renggali, (5) Kota Juang, (6) PT. BPRS Rahmania Sejahtera, (7) Hikmah Wakilah, (8) Rahman Hijrah Agung, (9) Adeco dan (10) Raihan.

\section{Teknik Pengumpulan Data}

Data yang digunakan dalam penelitian ini adalah data sekunder. Dalam penelitian ini pengumpulan data dilakukan dengan cara mengumpulkan laporan keuangan publikasi triwulanan BPRS di Aceh, yaitu laporan keuangan dari tahun 2010 sampai kuartal III tahun 2015, yang merupakan data time series. Data tersebut kemudian diklasifikasikan berdasarkan kriteria-kriteria yang telah ditentukan. Data-data ini diperoleh dari situs resmi Bank Indonesia yaitu www.bi.go.id.

\section{Definisi dan Operasional Variabel}

Penelitian ini menggunakan 6 (enam) variabel yang terdiri dari 2 (dua) variabel dependen dan 4 (empat) variabel independen. Variabel dependen dalam penelitian ini adalah profitabilitas yang diukur dengan menggunakan return on asset dan return on equity; sedangkan variabel independennya terdiri dari pembiayaan, dana pihak ketiga, financing to deposit ratio dan non performing financing. 


\section{Variabel Dependen (Y)}

Variabel dependen (variabel terikat) dinyatakan dengan notasi Y, variabel dependen dalam penelitian ini adalah profitabilitas yang diukur dengan menggunakan:

a) Return on asset, rumusnya adalah sebagai berikut:

Return on Asset $=\frac{\text { Laba Sesudah Pajak }}{\text { Total Aset }} \times 100 \%$

b) Return on equity, rumusnya adalah sebagai berikut:

$$
\text { Return on Equity }=\frac{\text { Laba Sesudah Pajak }}{\text { Modal }} \times 100 \%
$$

\section{Variabel Independen $(\mathbf{X})$}

Variabel independen (variabel bebas) dinyatakan dengan notasi X, variabel independen dalam penelitian ini adalah:

a) Pembiayaan

Pembiayaan yang dimaksudkan di sini adalah total pembiayaan yang disalurkan oleh BPRS dengan prinsip murabahah, salam, istishna, mudharabah dan musyarakah pada setiap akhir triwulan.

Pembiayaan = Pembiayaan Prinsip Murabahah + Salam + Istishna + Mudharabah + Musyarakah

b) Dana Pihak Ketiga

Dana pihak ketiga yang dimaksudkan di sini meliputikeseluruhan dana yang masuk keBPRS yang berasal dari para nasabah, selain modal maupun pinjaman.

Dana Pihak Ketiga $=$ Penghimpunan Dana Prinsip Wadiah + Mudharabah

c) Financing to Deposit Ratio

Financing to deposit ratio merupakan rasio yang digunakan untuk mengukur komposisi jumlah pembiayaan yang diberikan dibandingkan dengan jumlah dana masyarakat yang digunakan. Rumus untuk mencari financing to deposit ratio adalah sebagai berikut:

Financing to Deposit Ratio

$$
=\frac{\text { Total Pembiayaan }}{\text { Dana Pihak Ketiga }} \times 100 \%
$$


d) Non Performing Financing

Non performing financing merupakan rasio yang digunakan untuk mengukur kemampuan manajemen BPRS dalam mengelola pembiayaan bermasalah yang ada dapat dipenuhi dengan aktiva produktif yang dimiliki oleh suatu BPRS. Rumusnya adalah sebagai berikut:

Non Performing Financing

$$
=\frac{\text { Total Pembiayaan Bermasalah }}{\text { Total Pembiayaan yang Disalurkan }} \times 100 \%
$$

Tabel 1. Operasional Variabel

\begin{tabular}{|c|l|l|c|}
\hline No. & Variabel & \multicolumn{1}{|c|}{ Pengukuran } & Skala \\
\hline 1. & $\begin{array}{l}\text { Return on } \\
\text { asset }\end{array}$ & $\begin{array}{l}\text { Diukur dengan rasio antara } \\
\text { laba sesudah pajak dengan } \\
\text { total aset. }\end{array}$ & Rasio \\
\hline 2. & $\begin{array}{l}\text { Return on } \\
\text { equity }\end{array}$ & $\begin{array}{l}\text { Diukur dengan rasio antara } \\
\text { laba sesudah pajak dengan } \\
\text { modal. }\end{array}$ & Rasio \\
\hline 3. & Pembiayaan & $\begin{array}{l}\text { Diukur dengan menjumlahkan } \\
\text { seluruh pembiayaan yang } \\
\text { disalurkan, yaitu pembiayaan } \\
\text { dengan prinsip murabahah, } \\
\text { salam, istishna, mudharabah } \\
\text { dan musyarakah. }\end{array}$ & Rasio \\
\hline 4. & $\begin{array}{l}\text { Dana pihak } \\
\text { ketiga }\end{array}$ & $\begin{array}{l}\text { Diukur dengan menjumlahkan } \\
\text { seluruh penghimpunan dana } \\
\text { yang dilakukan, yaitu } \\
\text { penghimpunan dana dengan } \\
\text { prinsip } \\
\text { mudharabah. }\end{array}$ & Rasio \\
\hline 5. & $\begin{array}{l}\text { Financing to } \\
\text { deposit ratio }\end{array}$ & $\begin{array}{l}\text { Diukur dengan rasio antara } \\
\text { total pembiayaan dengan total } \\
\text { dana pihak ketiga. }\end{array}$ & Rasio \\
\hline 6. & $\begin{array}{l}\text { Non } \\
\text { performing } \\
\text { financing }\end{array}$ & $\begin{array}{l}\text { Diukur dengan rasio antara } \\
\text { total pembiayaan bermasalah } \\
\text { dengan total pembiayaan } \\
\text { yang disalurkan. }\end{array}$ & Rasio \\
\hline
\end{tabular}




\section{Hipotesis}

Hipotesis dari penelitian ini adalah:

1. $\mathrm{Ha}_{1}$ : Pembiayaan berpengaruh terhadap return on assetBPRS di Aceh.

2. $\mathrm{Ha}_{2}$ : Dana pihak ketiga berpengaruh terhadap return on assetBPRS di Aceh.

3. $\mathrm{Ha}_{3}$ : Financing to deposit ratio berpengaruh terhadap return on assetBPRS di Aceh.

4. $\mathrm{Ha}_{4}$ : Non performing financing berpengaruh terhadap return on assetBPRS di Aceh.

5. $\mathrm{Ha}_{5}$ : Pembiayaan, dana pihak ketiga, financing to deposit ratio dan non performing financing berpengaruh terhadap return on assetBPRS di Aceh.

6. $\mathrm{Ha}_{6}$ : Pembiayaan berpengaruh terhadap return on equityBPRS di Aceh.

7. $\mathrm{Ha}_{7}$ : Dana pihak ketiga berpengaruh terhadap return on equityBPRS di Aceh.

8. $\mathrm{Ha}_{8}$ : Financing to deposit ratio berpengaruh terhadap return on equityBPRS di Aceh.

9. $\mathrm{Ha}_{9}$ : Non performing financing berpengaruh terhadap return on equityBPRS di Aceh.

10. $\mathrm{Ha}_{10}$ : Pembiayaan, dana pihak ketiga, financing to deposit ratio dan non performing financing berpengaruh terhadap return on equityBPRS di Aceh.

\section{Metode Analisis Data}

Analisis data dilakukan dengan menggunakan regresi linear berganda.Adapun model persamaan regresi linear berganda yang digunakan dalam penelitian ini adalah sebagai berikut:

$$
\begin{aligned}
& Y_{1}=a+b_{1} X_{1}+b_{2} X_{2}+b_{3} X_{3}+b_{4} X_{4}+e \\
& Y_{2}=a+b_{1} X_{1}+b_{2} X_{2}+b_{3} X_{3}+b_{4} X_{4}+e
\end{aligned}
$$

Keterangan:

$\mathrm{Y}_{1}=$ Return on asset

$\mathrm{Y}_{2}=$ Return on equity

$\mathrm{a}=$ Konstanta

$\mathrm{b}=$ Koefisien regresi

$\mathrm{X}_{1}=$ Pembiayaan

$\mathrm{X}_{2}=$ Dana pihak ketiga

$\mathrm{X}_{3}=$ Financing to deposit ratio 
$\mathrm{X}_{4}=$ Non performing financing

$\mathrm{e}=$ Standar error

Selanjutnya menggunakan Classical Normal Linear Regression Model (CNLRM) yang meliputi uji normalitas, uji autokorelasi, uji multikolinearitas dan uji heteroskedastisitas. Serta uji hipotesis yaitu uji F dan uji t.

\section{HASIL PEMBAHASAN}

\section{Tingkat Profitabilitas Bank Pembiayaan Rakyat Syariah}

Berdasarkan data yang terkumpul diperoleh gambaran tentang tingkat profitabilitas BPRS di Aceh selama periode tahun 2010 hingga kuartal III tahun 2015. Nilai ROA terendah dialami oleh BPRS Renggali di Aceh Tengah pada bulan Juni tahun 2011 yaitu sebesar $0,12 \%$. Sedangkan nilai ROA tertinggi dialami oleh BPRS Ar-Raihan di Kota Langsa pada bulan Juni tahun 2013 yaitu sebesar 114,19\%, dan rata-rata ROA adalah $5,82 \%$. Sedangkan nilai ROE terendah dialami oleh BPRS Tgk. Chiek Dipante di Pidie pada bulan September tahun 2015 yaitu sebesar 0,29\%. Sedangkan nilai ROE tertinggi dialami oleh BPRS Ar-Raihan di Kota Langsa pada bulan Desember tahun 2012 yaitu sebesar 213,42\%, dan rata-rata ROE adalah 14,90\%.

\section{Hasil Pengujian Classical Normal Linear Regression Model (CNLRM)}

Sebelum melakukan pengujian hipotesis dengan regresi linear berganda, terlebih dahulu dilakukan pengujian Classical Normal Linear Regression Model. Uji ini dilakukan untuk mengetahui apakah model estimasi yang digunakan memenuhi asumsi regresi linear klasik. Di mana dalam penelitian ini ada 4 (empat) jenis pengujian yang digunakan, yaitu:

\section{a) Uji Normalitas}

Pengujian normalitas yang dilakukan dengan memakai uji Kolmogorov-Smirnov (KS) dengan menggunakan nilai Asymp. Sig. (2-tailed) $>$ dari tingkat Alpha 5\% untuk menunjukkan bahwa data terdistribusi normal. Hal tersebut dapat dilihat dari tabel 9 berikut: 
Iqtishadia, Vol. 9, No. 2, 2016

Tabel 2.Uji Normalitas

One-Sample Kolmogorov-Smirnov Test

\begin{tabular}{|c|c|c|c|c|c|c|c|}
\hline & & $\begin{array}{c}\text { Profitabi } \\
\text { litas } \\
(\mathrm{ROA})\end{array}$ & $\begin{array}{l}\text { Profitabilitas } \\
\text { (ROE) }\end{array}$ & $\begin{array}{c}\text { Pembiayaa } \\
n\end{array}$ & $\begin{array}{l}\text { Dana Pihak } \\
\text { Ketiga }\end{array}$ & FDR & NPF \\
\hline \multicolumn{2}{|l|}{$\mathrm{N}$} & 140 & 140 & 140 & 140 & 140 & 140 \\
\hline \multirow[t]{2}{*}{$\begin{array}{l}\text { Normal } \\
\text { Parametersa,b }\end{array}$} & Mean & 1.2612 & 1.8648 & $\begin{array}{r}702862934 \\
2.86\end{array}$ & 9.592379 & $\begin{array}{r}82.88 \\
15\end{array}$ & $\begin{array}{r}1.026 \\
0\end{array}$ \\
\hline & $\begin{array}{l}\text { Std. } \\
\text { Deviation }\end{array}$ & .54510 & .52669 & $\begin{array}{r}444565974 \\
6.859\end{array}$ & .4435760 & $\begin{array}{r}17.25 \\
657\end{array}$ & $\begin{array}{r}.2260 \\
8\end{array}$ \\
\hline \multirow{3}{*}{$\begin{array}{l}\text { Most Extreme } \\
\text { Differences }\end{array}$} & Absolute & .095 & .093 & .074 & .109 & .092 & .098 \\
\hline & Positive & .095 & .066 & .074 & .040 & .075 & .098 \\
\hline & Negative & -.046 & -.093 & -.066 & -.109 & -.092 & -.079 \\
\hline \multicolumn{2}{|c|}{ Kolmogorov-Smirnov Z } & 1.130 & 1.102 & .877 & 1.292 & 1.090 & 1.159 \\
\hline \multicolumn{2}{|c|}{ Asymp. Sig. (2-tailed) } & .156 & .176 & .426 & .071 & 186 & .136 \\
\hline
\end{tabular}

a. Test distribution is Normal.

b. Calculated from data.

Pada tabel 2 dapat dilihat bahwa pengujian terhadap variabel-variabel yang diteliti memperlihatkan nilai Asymp. Sig. (2-tailed) $>$ dari tingkat Alpha 5\%. Hal ini menunjukkan bahwa data-data terdistribusi dengan normal.

Selanjutnya, hasil uji normalitas juga dapat dibuktikan dengan grafik P-Plot seperti yang terlihat pada gambar berikut:

\section{Gambar 2. Grafik P-Plot Hasil Pengujian Normalitas}




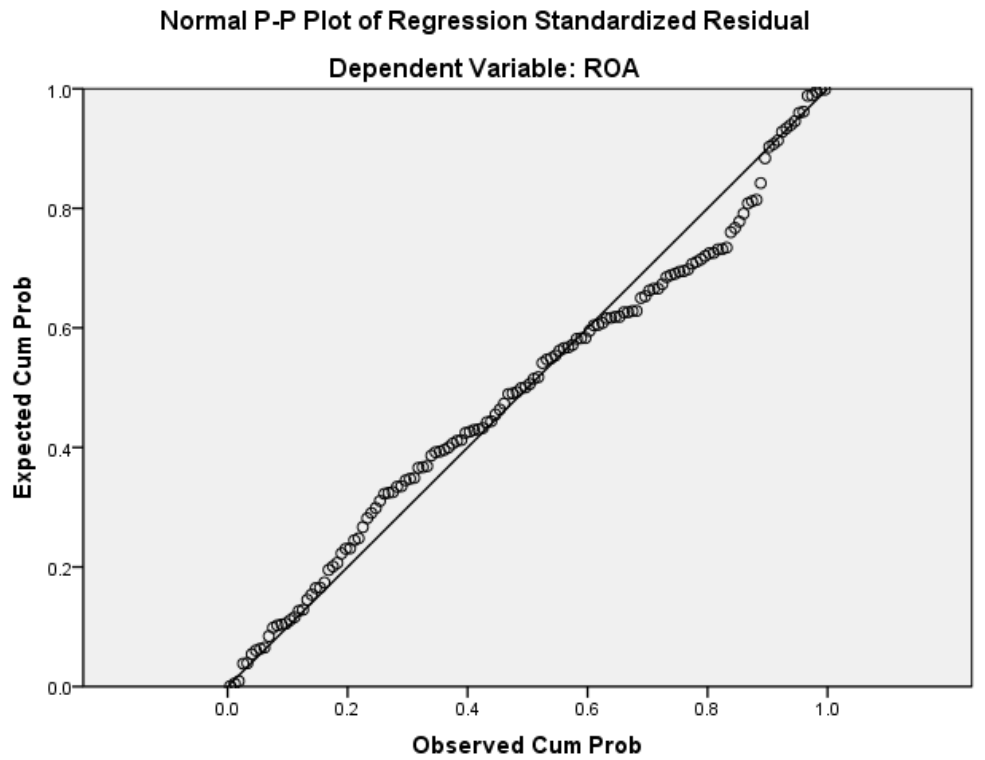

Normal P-P Plot of Regression Standardized Residual

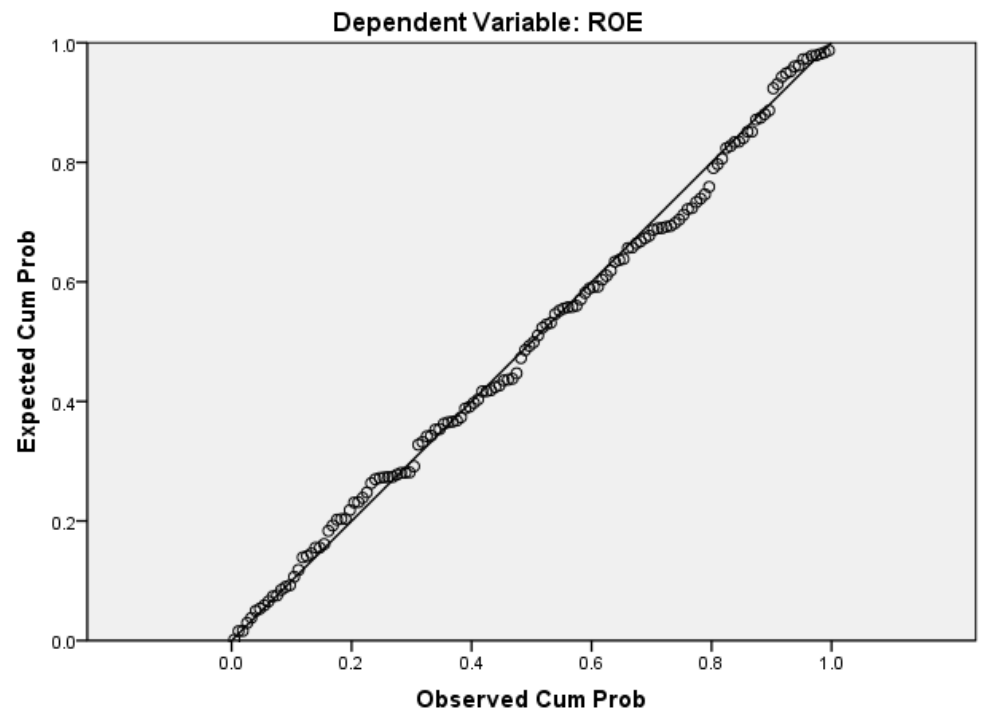

Dengan melihat grafik P-Plot di atas dapat disimpulkan bahwa grafik memberikan pola distribusi normal yang terlihat dari titik-titik menyebar di sekitar garis diagonal arah dan mengikuti garis diagonal, maka model regresi ini memenuhi asumsi normalitas. 


\section{b) Uji Autokorelasi}

Uji autokorelasi dilakukan dengan menggunakan uji Durbin-Watson (uji DW) dengan ketentuan jika angka DW dibawah -2 berarti ada autokorelasi positif, jika angka DW di antara -2 sampai +2 berarti tidak ada autokorelasi, dan jika angka DW di atas +2 berarti ada autokorelasi negatif. Untuk melihat hasil uji Durbin-Watson dalam penelitian ini dapat dilihat pada tabel 3untuk ROA sebagai variabel dependen dan tabel 4 untuk ROE sebagai variabel dependen:

\section{Tabel 3.Uji Autokorelasi}

\begin{tabular}{|l|r|r|r|r|r|}
\hline Model & R & R Square & $\begin{array}{c}\text { Adjusted R } \\
\text { Square }\end{array}$ & $\begin{array}{c}\text { Std. } \\
\text { Error of } \\
\text { the } \\
\text { Estimate }\end{array}$ & $\begin{array}{c}\text { Durbin } \\
- \\
\text { Watson }\end{array}$ \\
\hline 1 & $.576^{\mathrm{a}}$ & .332 & .313 & .45196 & 1.198 \\
\hline
\end{tabular}

a. Predictors: (Constant), NPF, Dana Pihak Ketiga, FDR, Pembiayaan

b. Dependent Variable: Profitabilitas (ROA)

\section{Tabel 4.Uji Autokorelasi}

\begin{tabular}{|l|l|r|r|r|r|}
\hline Model & R & R Square & $\begin{array}{c}\text { Adjusted R } \\
\text { Square }\end{array}$ & $\begin{array}{c}\text { Std. Error } \\
\text { of the } \\
\text { Estimate }\end{array}$ & $\begin{array}{c}\text { Durbin- } \\
\text { Watson }\end{array}$ \\
\hline 1 & $.422^{\mathrm{a}}$ & .178 & .153 & .48460 & 1.154 \\
\hline
\end{tabular}

a. Predictors: (Constant), NPF, Dana Pihak Ketiga, FDR, Pembiayaan b. Dependent Variable: Profitabilitas (ROE)

Dalam tabel 3 dapat dilihat bahwa hasil dari uji autokorelasi yang menggunakan uji Durbin-Watson memperoleh nilai 1,198 dan dalam tabel 4 hasil uji Durbin-Watson memperoleh nilai 1,154 . Hal tersebut menunjukkan bahwa tidak ada terjadinya autokorelasi.

\section{c) Uji Multikolinearitas}

Uji multikolinearitas di antara variabel independen dilihat dari nilai Variance Inflation Factors (VIF) dan nilai tolerance. Bila nilai VIF $>10$ atau nilai tolerance $<0,10$ maka ada 
multikolinearitas. Namun, bila nilai VIF $<10$ atau nilai tolerance $>0,10$ maka multikolinearitas ditolak. Berdasarkan uji multikolinearitas yang telah dilakukan, nilai VIF dan nilai tolerance untuk masing-masing variabel independen dapat dilihat pada tabel 5 berikut:

Tabel 5. Uji multikolinearitas

\begin{tabular}{|l|c|c|l|}
\hline \multicolumn{1}{|c|}{ Variabel Independen } & VIF & Tolerance & \multicolumn{1}{|c|}{ Keterangan } \\
\hline Pembiayaan & 4,904 & 0,204 & $\begin{array}{l}\text { Tidak ada } \\
\text { multikolinearitas }\end{array}$ \\
\hline Dana Pihak Ketiga & 4,902 & 0,204 & $\begin{array}{l}\text { Tidak ada } \\
\text { multikolinearitas }\end{array}$ \\
\hline FDR & 1,067 & 0,937 & $\begin{array}{l}\text { Tidak ada } \\
\text { multikolinearitas }\end{array}$ \\
\hline NPF & 1,126 & 0,888 & $\begin{array}{l}\text { Tidak ada } \\
\text { multikolinearitas }\end{array}$ \\
\hline
\end{tabular}

Sumber: data sekunder, diolah (2015)

Dari nilai VIF dan nilai tolerance yang diperoleh seperti tampak dalam tabel 5 menunjukkan tidak adanya korelasi antara variabel independen, di mana nilai VIF $<10$ dan nilai tolerance $>0,10$. Jadi, dapat disimpulkan tidak terdapat multikolinearitas di antara variabel independen.

\section{d) Uji Heteroskedastisitas}

Heteroskedastisitas akan mengakibatkan penafsiran koefisien regresi menjadi tidak efisien dan hasil penaksiran akan menjadi kurang dari semestinya. Heteroskedastisitas merupakan indikasi bahwa varian antar residual tidak homogen yang mengakibatkan nilai taksiran yang diperoleh tidak lagi efisien. Salah satu cara yang dapat digunakan untuk mendeteksi ada tidaknya heteroskedastisitas dapat dilakukan dengan uji glejser. Apabila tingkat signifikan masing-masing variabel independen di atas 5\%, maka dapat disimpulkan bahwa tidak terjadi heteroskedastisitas. Tingkat signifikan masing-masing variabel independen untuk return on asset sebagai variabel dependennya dan untuk return on equity sebagai variabel dependennya dapat dilihat pada tabel 6 dan tabel 7 berikut ini: 
Iqtishadia, Vol. 9, No. 2, 2016

Tabel 6. Uji Heteroskedastisitas (Return on Asset) Uji Glejser

\begin{tabular}{|c|c|c|c|c|c|}
\hline \multirow[t]{2}{*}{ Model } & \multicolumn{2}{|c|}{$\begin{array}{l}\text { Unstandardized } \\
\text { Coefficients }\end{array}$} & \multirow{2}{*}{$\begin{array}{c}\text { Standardized } \\
\text { Coefficients }\end{array}$} & \multirow[t]{2}{*}{$T_{\text {hitung }}$} & \multirow[t]{2}{*}{ Sig. } \\
\hline & B & Std. Error & & & \\
\hline 1 (Constant) & 1.205 & 1.092 & & 1.104 & .272 \\
\hline Pembiayaan & -1.697369 & .000 & -.251 & -1.408 & .161 \\
\hline $\begin{array}{l}\text { Dana Pihak } \\
\text { Ketiga }\end{array}$ & -.055 & .121 & -.082 & -.458 & .648 \\
\hline FDR & -.003 & .001 & -.161 & -1.937 & .055 \\
\hline NPF & .005 & .114 & .004 & .046 & .963 \\
\hline
\end{tabular}

a. Dependent Variable: absu

b. ROA

Tabel 7. Uji Heteroskedastisitas (Return on Equity)

Uji Glejser

\begin{tabular}{|l|r|r|r|r|r|}
\hline Model & \multicolumn{2}{|c|}{$\begin{array}{c}\text { Unstandardized } \\
\text { Coefficients }\end{array}$} & \multicolumn{1}{c|}{$\begin{array}{c}\text { Standardized } \\
\text { Coefficients }\end{array}$} & \multirow{2}{*}{$T_{\text {hitung }}$} & \multirow{2}{*}{ Sig. } \\
\cline { 2 - 3 } & \multicolumn{1}{|c|}{ B } & Std. Error & \multicolumn{1}{c|}{ Beta } & & \\
\hline 1 (Constant) & .180 & 1.081 & & .167 & .868 \\
Pembiayaan & -1.953348 & .000 & -.296 & -1.638 & .104 \\
Dana Pihak & .016 & .120 & .024 & .130 & .896 \\
Ketiga & & & & & \\
FDR & .000 & .001 & .020 & .233 & .816 \\
NPF & .152 & .112 & .117 & 1.349 & .180 \\
\hline
\end{tabular}

a. Dependent Variable: absu

b. ROE

Berdasarkan tabel 6 dan tabel 7 dapat dijelaskan bahwa tingkat signifikansi masing-masing variabel independen di atas $5 \%$, maka dapat disimpulkan bahwa asumsi heteroskedastisitas dapat ditolak. 


\section{Hasil Pengujian Hipotesis}

Hasil Pengujian Hipotesis dengan Return on Asset sebagai variabel dependen

Hasil pengujian regresi linear berganda dengan return on asset sebagai variabel dependen secara rinci dapat dilihat pada tabel 8 berikut ini:

Tabel 8.Hasil Pengujian Regresi Pengaruh Pembiayaan, Dana Pihak Ketiga, FDR dan NPF terhadap Return on Asset

\begin{tabular}{|c|c|c|c|c|c|}
\hline \multirow{2}{*}{ Model } & \multicolumn{2}{|c|}{$\begin{array}{l}\text { Unstandardized } \\
\text { Coefficients }\end{array}$} & \multirow{2}{*}{$\begin{array}{c}\begin{array}{c}\text { Standar } \\
\text { dized } \\
\text { Coefficie } \\
\text { nts }\end{array} \\
\text { Beta }\end{array}$} & \multirow{2}{*}{$\mathbf{T}_{\text {hitung }}$} & \multirow{2}{*}{ Sig. } \\
\hline & B & $\begin{array}{l}\text { Std. } \\
\text { Error }\end{array}$ & & & \\
\hline 1 (Constant) & 13.093 & 1.730 & & 7.567 & .000 \\
\hline Pembiayaan & 6.956053 & .000 & .567 & 3.643 & .000 \\
\hline $\begin{array}{l}\text { Dana Pihak } \\
\text { Ketiga }\end{array}$ & -1.184 & .191 & -.963 & -6.186 & .000 \\
\hline FDR & -.007 & .002 & -.226 & -3.109 & .002 \\
\hline NPF & -.366 & .180 & -.152 & -2.033 & .044 \\
\hline $\begin{array}{l}\text { Koefisien De } \\
\left(\mathrm{R}^{2}\right)\end{array}$ & $\begin{array}{l}(\mathrm{R}) \\
\text { tasi }\end{array}$ & $\begin{array}{l}.576 \\
.332\end{array}$ & & & \\
\hline
\end{tabular}

Dari perhitungan statistik dengan menggunakan bantuan program SPSS seperti terlihat pada tabel 8 maka diperoleh persamaan regresi berganda sebagai berikut:

$$
Y_{1}=13.093+6.956 X_{1}-1.184 X_{2}-0.007 X_{3}-0.366 X_{4}+e
$$

Berdasarkan hasil persamaan regresi linear berganda tersebut dapat diketahui hasil penelitian sebagai berikut:

\section{Koefisien Regresi $(\boldsymbol{\beta})$}

a. Constant (konstanta) sebesar 13,093 artinya jika variabel pembiayaan, dana pihak ketiga, financing to deposit 
ratio dan non performing financing dianggap konstan maka besarnya variabel return on asset sebesar 13,093\%.

b. Koefisien regresi variabel pembiayaan $\left(\mathrm{X}_{1}\right)$ sebesar 6,956 yang artinya jika nilai variabel pembiayaan meningkat sebesar satu juta rupiah, maka akan mengakibatkan peningkatan return on asset sebesar $6,956 \%$ dengan asumsi variabel lain dianggap konstan. Jadi, semakin tinggi jumlah pembiayaan maka return on asset akan semakin tinggi.

c. Koefisien regresi variabel dana pihak ketiga $\left(\mathrm{X}_{2}\right)$ sebesar $-1,184$ yang artinya jika nilai variabel dana pihak ketiga meningkat sebesar satu juta rupiah, maka akan mengakibatkan penurunan return on asset sebesar $1,184 \%$ dengan asumsi variabel lain dianggap konstan. Jadi, semakin tinggi jumlah dana pihak ketiga maka return on asset akan semakin rendah.

d. Koefisien regresi variabel financing to deposit ratio $\left(\mathrm{X}_{3}\right)$ sebesar -0,007 yang artinya jika nilai variabel financing to deposit ratio meningkat sebesar satu persen, maka akan mengakibatkan penurunan return on asset sebesar $0,007 \%$ dengan asumsi variabel lain dianggap konstan. Jadi, semakin tinggi jumlah financing to deposit ratio maka return on asset akan semakin rendah.

e. Koefisien regresi variabel non performing financing $\left(\mathrm{X}_{4}\right)$ sebesar -0,366 yang artinya jika nilai variabel non performing financing meningkat sebesar satu persen, maka akan mengakibatkan penurunan return on asset sebesar 0,336\% dengan asumsi variabel lain dianggap konstan. Jadi, semakin tinggi jumlah non performing financing maka return on asset akan semakin rendah.

\section{Koefisien Korelasi (R)}

Koefisien korelasi $(\mathrm{R})=0,576$ menunjukkan bahwa hubungan keeratan antara variabel dependen (return on asset) yang dapat dijelaskan oleh variabel independen (pembiayaan, dana pihak ketiga, financing to deposit ratio, dan non performing financing) adalah sebesar 57,6\%. Hal ini menunjukkan bahwa pembiayaan, dana pihak ketiga, financing to deposit ratio, dan non performing financing mempunyai pengaruh yang cukup kuat terhadap return on asset pada BPRS 
yang dijadikan sampel. Sedangkan selebihnya yaitu 0,424 $(42,4 \%)$ dipengaruhi oleh variabel-variabel lain yang tidak diamati dalam penelitian ini.

\section{Koefisien Determinasi $\left(\mathbf{R}^{2}\right)$}

Koefisien determinasi $\left(\mathrm{R}^{2}\right)=0,332$ yang berarti sebesar $33,2 \%$ perubahan-perubahan dalam variabel dependen (return on asset) dapat dijelaskan oleh perubahan-perubahan dari pembiayaan, dana pihak ketiga, financing to deposit ratio dan non performing financing. Hal ini menunjukkan bahwa pembiayaan, dana pihak ketiga, financing to deposit ratio dan non performing financing memiliki pengaruh terhadap return on asset.

\section{Pengujian Hipotesis Secara Simultan (Uji F)}

Untuk menguji apakah pembiayaan, dana pihak ketiga, financing to deposit ratio dan non performing financing berpengaruh terhadap return on asset pada BPRS di Aceh secara simultan (bersama-sama) digunakan uji $F$ statistik seperti tampak pada tabel 9 berikut ini:

Tabel 9. Pengujian Hipotesis Secara Simultan ANOVA ${ }^{b}$

\begin{tabular}{|c|c|c|c|c|c|}
\hline Model & $\begin{array}{c}\text { Sum of } \\
\text { Squares }\end{array}$ & Df & $\begin{array}{c}\text { Mean } \\
\text { Square }\end{array}$ & $\mathbf{F}$ & Sig. \\
\hline 1 Regression & 13.726 & 4 & 3.431 & 16.798 & $.000^{\mathrm{a}}$ \\
\hline Residual & 27.577 & 135 & .204 & & \\
\hline Total & 41.302 & 139 & & & \\
\hline
\end{tabular}

Pada tabel 9 dapat dilihat bahwa tingkat signifikansi sebesar 0,000 (lebih kecil dari $\alpha=0,05$ ). Nilai ini dapat membuktikan bahwa hipotesis alternatif $\left(\mathrm{Ha}_{5}\right)$ yang diajukan dapat diterima. Kesimpulan yang dapat diambil adalah pembiayaan, dana pihak ketiga, financing to deposit ratio dan non performing financing secara simultan berpengaruh terhadap return on asset pada BPRS di Aceh yang dijadikan sampel dalam penelitian ini. 


\section{Pengujian Hipotesis Secara Parsial (Uji t)}

Berdasarkan tabel 8 , hasil penelitian terhadap variabel pembiayaan menunjukkan nilai signifikansinya sebesar 0,000 atau < 0,05. Maka $\mathrm{Ha}_{1}$ diterima. Dengan demikian hasil perhitungan statistik menunjukkan bahwa secara parsial variabel pembiayaan berpengaruh positif terhadap return on asset. Untuk hasil penelitian terhadap variabel dana pihak ketiga menunjukkan nilai signifikansinya sebesar 0,000 atau $<0,05$. Maka $\mathrm{Ha}_{2}$ diterima. Hal ini menunjukkan bahwa secara parsial variabel dana pihak ketiga berpengaruh negatif terhadap return on asset.

Hasil penelitian terhadap variabel financing to deposit ratio menunjukkan nilai signifikansinya sebesar 0,002 atau < 0,05. Maka $\mathrm{Ha}_{3}$ diterima. Dengan demikian hasil perhitungan statistik menunjukkan bahwa secara parsial variabel financing to deposit ratio berpengaruh negatif terhadap return on asset. Kemudian, hasil penelitian terhadap variabel non performing financing menunjukkan nilai signifikansinya sebesar 0,044 atau $<0,05$. Maka $\mathrm{Ha}_{4}$ diterima. Hal ini juga menunjukkan bahwa secara parsial variabel non performing financing berpengaruh negatif terhadap return on asset.

\section{Hasil Pengujian Hipotesis dengan Return on Equity sebagai variabel dependen}

Hasil pengujian regresi linear berganda dengan return on equity sebagai variabel dependen secara rinci dapat dilihat pada tabel 10 berikut ini:

\section{Tabel 10.Hasil Pengujian Regresi Pengaruh Pembiayaan, Dana Pihak Ketiga, FDR dan NPF terhadap Return on Equity}

\begin{tabular}{|l|r|r|r|r|r|}
\hline \multirow{2}{*}{ Model } & \multicolumn{2}{|c|}{$\begin{array}{c}\text { Unstandardized } \\
\text { Coefficients }\end{array}$} & $\begin{array}{c}\text { Standardized } \\
\text { Coefficients }\end{array}$ & \multirow{2}{*}{ Thitung } & Sig. \\
\cline { 2 - 4 } & \multicolumn{1}{|c|}{ B } & Std. Error & \multicolumn{1}{c|}{ Beta } & & \\
\hline 1 (Constant) & 7.189 & 1.855 & & 3.875 & .000 \\
Pembiayaan & 3.753398 & .000 & .317 & 1.833 & .069 \\
Dana Pihak Ketiga & -.444 & .205 & -.374 & -2.166 & .032 \\
FDR & -.012 & .002 & -.398 & -4.937 & .000
\end{tabular}




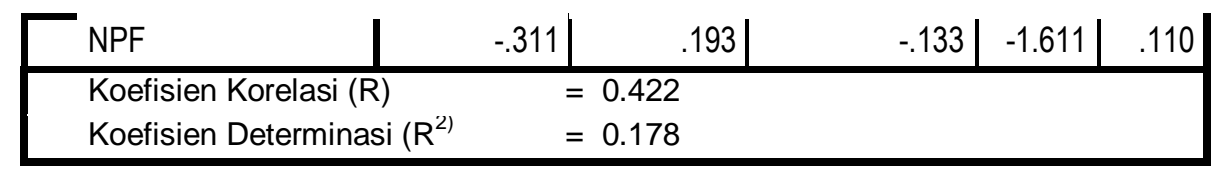

Dari perhitungan statistik dengan menggunakan program SPSS seperti terlihat pada tabel 10 maka diperoleh persamaan regresi berganda sebagai berikut:

$$
\mathrm{Y}_{2}=7,189+3,753 \mathrm{X}_{1}-0,444 \mathrm{X}_{2}-0,012 \mathrm{X}_{3}-0,311 \mathrm{X}_{4}+\mathrm{e}
$$

Berdasarkan hasil persamaan regresi linear berganda tersebut dapat diketahui hasil penelitian sebagai berikut:

\section{Koefisien Regresi $(\boldsymbol{\beta})$}

a. Constant (konstanta) sebesar 7,189 artinya jika variabel pembiayaan, dana pihak ketiga, financing to deposit ratio dan non performing financing dianggap konstan maka besarnya variabel return on equity sebesar 7,189\%.

b. Koefisien regresi variabel pembiayaan $\left(\mathrm{X}_{1}\right)$ sebesar 3,753 yang artinya jika nilai variabel pembiayaan meningkat sebesar satu juta rupiah, maka akan mengakibatkan peningkatan return on equity sebesar $3,753 \%$ dengan asumsi variabel lain dianggap konstan. Jadi, semakin tinggi jumlah pembiayaan maka return on equity akan semakin tinggi.

c. Koefisien regresi variabel dana pihak ketiga $\left(\mathrm{X}_{2}\right)$ sebesar $-0,444$ yang artinya jika nilai variabel dana pihak ketiga meningkat sebesar juta rupiah, maka akan mengakibatkan penurunan return on equity sebesar $0,444 \%$ dengan asumsi variabel lain dianggap konstan. Jadi, semakin tinggi jumlah dana pihak ketiga maka return on equity akan semakin rendah.

d. Koefisien regresi variabel financing to deposit ratio $\left(\mathrm{X}_{3}\right)$ sebesar -0,012 yang artinya jika nilai variabel financing to deposit ratio meningkat sebesar satu persen, maka akan mengakibatkan penurunan return on equity sebesar $0,012 \%$ dengan asumsi variabel lain dianggap konstan. Jadi, semakin tinggi jumlah financing to deposit ratio maka return on equity akan semakin rendah.

e. Koefisien regresi variabel non performing financing $\left(\mathrm{X}_{4}\right)$ sebesar -0,311 yang artinya jika nilai variabel non performing financing meningkat sebesar satu persen, 
maka akan mengakibatkan penurunan return on equity sebesar 0,311 dengan asumsi variabel lain dianggap konstan. Jadi, semakin tinggi jumlah non performing financing maka return on equity akan semakin rendah.

\section{Koefisien Korelasi $(\mathbf{R})$}

Koefisien korelasi $(\mathrm{R})=0,422$ menunjukkan bahwa hubungan keeratan antara variabel dependen (return on equity) yang dapat dijelaskan oleh variabel independen (pembiayaan, dana pihak ketiga, financing to deposit ratio, dan non performing financing) adalah sebesar 42,2\%. Hal ini menunjukkan bahwa pembiayaan, dana pihak ketiga, financing to deposit ratio, dan non performing financing mempunyai pengaruh yang cukup kuat terhadap return on equity pada BPRS yang dijadikan sampel. Sedangkan selebihnya yaitu 0,578 $(57,8 \%)$ dipengaruhi oleh variabel-variabel lain yang tidak diamati dalam penelitian ini.

\section{Koefisien Determinasi $\left(\mathbf{R}^{2}\right)$}

Koefisien determinasi $\left(\mathrm{R}^{2}\right)=0,178$ yang berarti sebesar $17,8 \%$ perubahan-perubahan dalam variabel dependen (return on equity) dapat dijelaskan oleh perubahan-perubahan dari pembiayaan, dana pihak ketiga, financing to deposit ratio, dan non performing financing. Hal ini menunjukkan bahwa pembiayaan, dana pihak ketiga, financing to deposit ratio, dan non performing financing memiliki pengaruh terhadap return on equity.

\section{Pengujian Hipotesis Secara Simultan (Uji F)}

Untuk menguji apakah pembiayaan, dana pihak ketiga, financing to deposit ratio, dan non performing financing berpengaruh terhadap return on equity pada BPRS di Aceh secara simultan (bersama-sama) digunakan uji F statistik seperti tampak pada tabel 11 berikut ini: 
Tabel 11. Pengujian Hipotesis Secara Simultan ANOVA $^{b}$

\begin{tabular}{|c|c|c|c|c|c|}
\hline Model & $\begin{array}{c}\text { Sum of } \\
\text { Squares }\end{array}$ & Df & $\begin{array}{c}\text { Mean } \\
\text { Square } \\
\end{array}$ & $\mathbf{F}$ & Sig. \\
\hline 1 Regression & 6.856 & 4 & 1.714 & 7.299 & $.000^{\mathrm{a}}$ \\
\hline Residual & 31.703 & 135 & .235 & & \\
\hline Total & 38.559 & 139 & & & \\
\hline
\end{tabular}

Pada tabel 11 dapat dilihat bahwa tingkat signifikansi sebesar 0,000 (lebih kecil dari $\alpha=0,05$ ). Nilai ini dapat membuktikan bahwa hipotesis alternatif $\left(\mathrm{Ha}_{10}\right)$ yang diajukan dapat diterima. Kesimpulan yang dapat diambil adalah pembiayaan, dana pihak ketiga, financing to deposit ratio, dan non performing financing secara simultan berpengaruh terhadap return on equity pada BPRS di Aceh yang dijadikan sampel dalam penelitian ini.

\section{Pengujian Hipotesis Secara Parsial (Uji t)}

Berdasarkan tabel 10 di atas, hasil penelitian terhadap variabel pembiayaan menunjukkan nilai signifikansinya sebesar 0,069 atau > 0,05. Maka $\mathrm{Ha}_{6}$ ditolak. Dengan demikian hasil perhitungan statistik menunjukkan bahwa secara parsial variabel pembiayaan tidak berpengaruh terhadap return on equity. Untuk hasil penelitian terhadap variabel dana pihak ketiga menunjukkan nilai signifikansinya sebesar 0,032 atau $<0,05$. Maka $\mathrm{Ha}_{7}$ diterima. Hal ini menunjukkan bahwa secara parsial variabel dana pihak ketiga berpengaruh negatif terhadap return on equity.

Hasil penelitian terhadap variabel financing to deposit ratio menunjukkan nilai signifikansinya sebesar 0,000 atau < 0,05. Maka $\mathrm{Ha}_{8}$ diterima. Dengan demikian hasil perhitungan statistik menunjukkan bahwa secara parsial variabel financing to deposit ratio berpengaruh negatif terhadap return on equity. Kemudian, hasil penelitian terhadap variabel non performing financing menunjukkan nilai signifikansinya sebesar 0,110 atau $>$ 0,05. Maka Ha9 ditolak. Hal ini menunjukkan bahwa secara parsial variabel non performing financing tidak berpengaruh terhadap return on equity. Artinya kondisi NPF yang lebih besar dalam satu periode tidak secara langsung memberikan 
penurunan laba pada periode yang sama. Hal ini dikarenakan pengaruh yang signifikan dari NPF terhadap ROE adalah berkaitan dengan penentuan tingkat kemacetan pembiayaan yang diberikan oleh sebuah bank.

\section{PENUTUP}

Penelitian ini dilakukan untuk menguji pengaruh pembiayaan, dana pihak ketiga, financing to deposit ratio dan non performing financing terhadap tingkat profitabilitas pada BPRS di Aceh. Profitabilitas dalam penelitian ini sendiri diukur dengan menggunakan dua rasio yaitu return on asset dan return on equity. Dari hasil penelitian dan pembahasan yang telah diuraikan di atas, maka penulis mengambil beberapa kesimpulan

1. Dari hasil pengolahan data dengan return on asset sebagai variabel dependen diperoleh nilai koefisien korelasi (R) atau korelasi antara variabel bebas dengan variabel tergantungnya adalah sebesar 0,576 atau $57,6 \%$ yang menunjukkan bahwa antara variabel dependen (return on asset) dan variabel independen (pembiayaan, dana pihak ketiga, financing to deposit ratio dan non performing financing) mempunyai hubungan yang cukup kuat yaitu sebesar 57,6\%. Sedangkan selebihnya yaitu 0,424 atau $42,4 \%$ dipengaruhi oleh variabel-variabel lain yang tidak diamati dalam penelitian ini. Selanjutnya diperoleh nilai koefisien determinasi $\left(\mathrm{R}^{2}\right)$ sebesar 0,332 atau 33,2\%. Angka ini menunjukkan bahwa sebesar $33,2 \%$ perubahanperubahan dalam return on asset dapat dijelaskan oleh perubahan-perubahan dari pembiayaan, dana pihak ketiga, financing to deposit ratio dan non performing financing.

2. Dari hasil pengolahan data dengan return on equity sebagai variabel dependen diperoleh nilai koefisien korelasi (R) atau korelasi antara variabel bebas dengan variabel tergantungnya adalah sebesar 0,422 atau $42,2 \%$ yang menunjukkan bahwa antara variabel dependen (return on equity) dan variabel independen (pembiayaan, dana pihak ketiga, financing to deposit ratio dan non performing financing) mempunyai hubungan yang cukup kuat yaitu sebesar 42,2\%. Sedangkan selebihnya yaitu 0,578 atau $57,8 \%$ dipengaruhi oleh variabel-variabel lain yang tidak 
diamati dalam penelitian ini. Selanjutnya diperoleh nilai koefisien determinasi $\left(\mathrm{R}^{2}\right)$ sebesar 0,178. Angka ini menunjukkan bahwa sebesar $17,8 \%$ perubahan-perubahan dalam return on equity dapat dijelaskan oleh perubahanperubahan dari pembiayaan, dana pihak ketiga, financing to deposit ratio dan non performing financing.

3. Dari pengujian simultan (uji F) dengan return on asset sebagai variabel dependen diperoleh nilai signifikansi sebesar 0,000 atau $<0,05$ yang membuktikan bahwa pembiayaan, dana pihak ketiga, financing to deposit ratio dan non performing financing secara simultan berpengaruh signifikan terhadap return on asset pada BPRS di Aceh.Artinya secara bersama-sama pembiayaan, dana pihak ketiga, financing to deposit ratio dan non performing financingmemiliki pengaruh yang sangat tinggiterhadap tingkat profitabilitas yang diukur dengan return on assetpada BPRS di Aceh.

4. Dari pengujian simultan (uji F) dengan return on equity sebagai variabel dependen juga diperoleh nilai signifikansi sebesar 0,000 atau < 0,05 yang membuktikan bahwa pembiayaan, dana pihak ketiga, financing to deposit ratio dan non performing financing secara simultan berpengaruh signifikan terhadap return on equity. Artinya secara bersama-sama pembiayaan, dana pihak ketiga, financing to deposit ratio dan non performing financingmemiliki pengaruh yang sangat tinggi terhadap tingkat profitabilitas yang diukur dengan return on equity pada BPRS di Aceh.

5. Hasil pengujian secara parsial (uji t) dengan return on asset sebagai variabel dependen menunjukkan pembiayaan memiliki nilai signifikansi 0,000 atau $<0,05$ yang membuktikan bahwa pembiayaan berpengaruh signifikan terhadap return on asset. Sedangkan hasil pengujian secara parsial (uji t) dengan return on equity sebagai variabel dependen menunjukkan pembiayaan memiliki nilai signifikansi 0,069 atau $>0,05$ yang berarti pembiayaan tidak berpengaruh signifikan terhadap return on equity. Artinya jika diuji masing-masing, pembiayaan memiliki pengaruh yang sangat tinggi terhadap return on asset tetapi tidak memiliki pengaruh terhadap tinggi atau rendahnya return on equity. 
6. Hasil pengujian secara parsial (uji t) dengan return on asset sebagai variabel dependen menunjukkan dana pihak ketiga memiliki nilai signifikansi 0,000 atau $<0,05$ yang membuktikan bahwa dana pihak ketiga berpengaruh signifikan terhadap return on asset. Untuk hasil pengujian secara parsial (uji t) dengan return on equity sebagai variabel dependen menunjukkan pembiayaan memiliki nilai signifikansi 0,032 atau $<0,05$ yang menunjukkan bahwa dana pihak ketiga juga berpengaruh signifikan terhadap return on equity. Artinya jika diuji masing-masing, dana pihak ketiga memiliki pengaruh yang tinggi terhadap return on asset dan memiliki pengaruh yang rendah terhadap return on equity.

7. Hasil pengujian secara parsial (uji t) dengan return on asset sebagai variabel dependen menunjukkan financing to deposit ratio memiliki nilai signifikansi 0,002 atau $<0,05$ yang membuktikan bahwa financing to deposit ratio berpengaruh signifikan terhadap return on asset. Untuk hasil pengujian secara parsial (uji t) dengan return on equity sebagai variabel dependen menunjukkan pembiayaan memiliki nilai signifikansi 0,000 atau $<0,05$ yang menunjukkan bahwa financing to deposit ratio juga berpengaruh signifikan terhadap return on equity. Artinya jika diuji masing-masing, financing to deposit ratio memiliki pengaruh yang tinggi terhadap return on asset dan juga terhadap return on equity.

8. Hasil pengujian secara parsial (uji t) dengan return on asset sebagai variabel dependen menunjukkan non performing financing memiliki nilai signifikansi 0,044 atau < 0,05 yang membuktikan bahwa non performing financing berpengaruh signifikan terhadap return on asset. Sedangkan hasil pengujian secara parsial (uji t) dengan return on equity sebagai variabel dependen menunjukkan non performing financing memiliki nilai signifikansi 0,110 atau > 0,05 yang berarti non performing financing tidak berpengaruh signifikan terhadap return on equity. Artinya jika diuji masing-masing, non performing finance memiliki pengaruh yang rendah terhadap return on asset tetapi tidak berpengaruh terhadap tinggi rendahnya return on equity. 
Berdasarkan kesimpulan yang telah dijelaskan di atas, maka peneliti memberikan beberapa saran sebagai berikut:

1. BPRS harus terus meningkatkan kualitas pengelolaannya agar dapat memperoleh laba yang maksimal seperti yang telah ditargetkan. Hal ini dimaksudkan karena Bank Pembiayaan Rakyat Syariah sangat berperan dalam memperdayakan ekonomi golongan lemah, yaitu dengan mengembangkan Usaha Mikro, Kecil dan Menengah (UMKM).

2. BPRS harus melakukan perhitungan rasio-rasio keuangan yang terkait dengan penilaian tingkat kesehatan bank agar mengetahui gambaran yang lebih tepat mengenai kondisi bank saat ini dan mendatang.

3. Pihak BPRS harus mampu melakukan pengawasan yang lebih ketat terhadap pembiayaan-pembiayaan yang diberikan/disalurkan. Hal ini dimaksudkan untuk meningkatkan prinsip kehati-hatian sehingga dapat meminimalisasi non performing financing.

4. BPRS harus lebih inovatif dalam mengembangkan produkproduk yang ada dan tetap memperhatikan prinsip-prinsip syariah.

5. Pemerintah harus mendukung penuh terhadap proses pengembangan bank pembiyaan rakyat syariah, hal ini disebabkan karena bank pembiayaan rakyat syariah merupakan salah satu lembaga keuangan yang dapat menggerakkan perkembangan ekonomi mikro ke arah yang lebih baik.

6. Untuk penelitan yang akan datang dapat menambahkan variabel-variabel independen lain yang tidak dibahas dalam penelitian ini. Penelitian selanjutnya juga perlu menambah jumlah periode pengamatan ataupun mempertimbangkan sampel yang lebih luas dengan menambah data tidak hanya dari BPRS, tetapi juga dari bank umum syariah atau unit usaha syariah untuk mendapatkan hasil pengamatan yang lebih baik dan dapat mewakili keseluruhan populasi bank syariah. 


\section{DAFTAR PUSTAKA}

Anggreni, Made Ria, dan I Made Sadha Suardhika. (2014). Pengaruh Dana Pihak Ketiga, Kecukupan Modal, Risiko Kredit dan Suku Bunga Kredit pada Profitabilitas. EJurnal Akuntansi Universitas Udayana, 9.

Arimi, M.dan Kholiq Mahfud, M. (2012). Analisis FaktorFaktor yang Mempengaruhi Profitabilitas Perbankan (Studi pada Bank Umum yang Listed di Bursa Efek Indonesia Tahun 2007-2010). Diponegoro Journal of Management, 1(2).

Danuprata, Gita. (2015). Buku Ajar Manajemen Perbankan Syaria. Salemba Empat. Jakarta.

Fahrul, F.Arfan, M. dan Darwanis. (2012). Pengaruh Tingkat Risiko Pembiayaan Musyarakah dan Pembiayaan Murabahah terhadap Tingkat Profitabilitas Bank Syariah (Studi pada Bank Aceh Syariah Cabang Banda Aceh).Jurnal Akuntansi Pascasarjana Universitas Syiah Kuala, 2(1).

Inti Dwi Permata, R., Yaningwati.F., dan Zahroh. (2014). Analisis Pengaruh Pembiayaan Mudharabah dan Musyarakah terhadap Tingkat Profitabilitas (Return on Equity) (Studi pada Bank Umum Syariah yang Terdaftar di Bank Indonesia Periode 2009-2012).Jurnal Administrasi Bisnis, 12.

Iska. S. (2012). Sistem Perbankan Syariah di Indonesia dalam Perspekif Fikih Ekonomi.Fajar Media Press. Yogyakarta.

Kasmir. (2011). Analisis Laporan Keuangan. Rajawali Pers, Jakarta.

Kasmir. (2015). Pengantar Manajemen Keuangan. Kencana, Jakarta.

Peraturan Bank Indonesia Nomor 11/23/PBI/2009 tentang Bank Pembiayaan Rakyat Syariah.

Soemitral, A. (2012). Bank dan Lembaga Keuangan Syariah. Kencana. Jakarta.

Sugiyono. (2012). Metode Penelitian Bisnis (Pendekatan Kuantitatif, Kualitatif, dan $R \& D)$ ). Alvabeta, Bandung.

Sugiyono. (2014). Metode Penelitian Kombinasi (Mixed Methods). Alvabeta, Bandung. 
Suryani. (2011). Analisis Pengaruh Financing to Deposit Ratio (FDR) terhadap Profitabilitas Perbankan Syariah di Indonesia.Walisongo, 19(1).

Syafi'i Antonio, M.(2008). Bank Syariah: Analisis Kekuatan, Kelemahan, Peluang dan Ancaman. Ekonisia,Yogyakarta.

Syamsudin, L. (2011). Manajemen Keuangan Perusahaan (Konsep Aplikasi dalam Perencanaan, Pengawasan dan Pengambilan Keputusan). PT Raja Grafindo Persada, Jakarta.

Undang-Undang Republik Indonesia Nomor 21 Tahun 2008 tentang Perbankan Syariah. 